REFLECTIONS:

NEUROLOGY AND THE

HUMANITIES

Section Editor

Michael H. Brooke, MD

\title{
The Carnival
}

Anthony Adamo, DO

Address correspondence and reprint requests to Dr. Anthony Adamo, Nassau Suffolk Neurology, Suite 222, 400 West Main Street, Babylon, NY 11702 adamofamily@juno.com
When I was a young boy, my parents took me to a traveling country carnival in upstate New York where my grandparents lived. In the days before children became mesmerized by computer-generated animated movies and entranced by the hypnotic glow of the video screen, the country fair was a major form of public entertainment. The Ferris wheels and roller coasters offered the promise of experiencing such exciting and frightening neurologic symptoms as acute vertigo and disequilibrium, along with the occasional unintended nausea and vomiting. As twilight approached on that summer evening my parents and I wandered to the darkened periphery of the fairground, away from the buzzing noises and bright lights. We slowly approached a small rectangular tent with a pitched rooftop. A string of incandescent light bulbs softly illuminated the flimsy structure. I clearly remember the small sign (or warning) outside the doorway stating "This Exhibit Not For Entertainment."

Once inside, my parents assumed a somber and almost pious silence. The large rectangular room was very quiet, the walls lined with shelves that housed glass jars of various sizes. Each receptacle contained a fetus, some relatively normal looking, while others were so hideously deformed as to be unrecognizable as human. These pitiful creatures were of various stages of embryologic development. Some looked like normal term babies, some looked like large tadpoles, some had enormous swollen heads, tails, extra arms or legs or three eyes. Being a young science fiction enthusiast, I wondered if any one of them might be an extraterrestrial alien from perhaps the red sands of Mars or the stormy world of Jupiter. It was clear to me that none of them were alive and I thought this was certainly for the better. None of the jars were labeled and no explanation as to the origin of these loathsome creatures was offered. As we walked down the corridors, my parents would whisper and shake their heads. It became clear to me that this house of horrors was really a very sad place. Although at this young age I certainly did not possess the vocabulary or the intellect to frame analytical questions about the human brain, I still wondered about what human abilities these poor creatures may have once possessed. Did these sad beings think and feel? Did they have memories and emotions? Did they once have conscious awareness and recognize their miserable plight? Their images left an indelible impression on a young mind and still haunt me to this day.

It would be over two decades before I would revisit this place in another form, a modern child neurology clinic at the university hospital where I was a young neurologist in training. It would be here that I would finally gain some scientific understanding and perhaps some human insight into what I gazed upon so long ago. The university hospital clinic functions like a well-oiled machine at its best. Eager medical students, bright young resident physicians, and experienced attendings all fervently discussing cases both common and unusual. Such an antiseptic academic environment, however, may not seem conducive to producing awe and wonder. Nevertheless, I would often experience this sense just anticipating my weekly visit to this clinic. To be sure, there would be plenty of routine cases at our weekly sessions: autistic toddlers, children with epilepsy, patients with neurogenetic disorders like neurofibromatosis. Once a month, however, we would see children with profoundly devastating neurologic conditions, for whom no real treatment could be offered other than socalled supportive care. These tragic cases often prompted me to speculate about the human brain, consciousness, and memory. One particular case I most vividly recall.

Mary was the bright and perky young mother of three children, the youngest of which she would bring to our clinic every few months. This male child would come wrapped in blankets in a stroller. His mother would lovingly describe his eating schedule and bathing habits to us. His clothes and blankets were decorated with Disney cartoon characters. As I examined him for the first time, I realized this was a large baby with a big head. His eyes stared intently or darted about chaotically. The limbs would adjust position in a seemingly voluntary manner and I thought he cooed once or twice. As a young neurologist who was just starting to develop some self-confidence over my clinical skills, I was stunned when I learned that the baby was 3 and a half years old. Furthermore, this child had no brain. He was a terrible victim of an 
anencephalic-like syndrome. His head was mainly filled with fluid and a thin mantle of cerebral cortex. He could not think, learn, or remember in any real sense. He would never talk or walk. Most of what he did in life involved primitive brainstem reflexes. From what we know, no true self-awareness or capacity for memory or emotion could possibly exist. I immediately recalled the denizens of that sad carnival long ago. I realized that those poor creatures were human anencephalics and hydrocephalics who in life were trapped in a zombie-like state. They could never have known consciousness, memory, or emotion, at least not in the way that you and I experience them.

Somewhere along the way I learned that the historical meaning of Carnival-at least as it was known in the Middle Ages-involves the celebration of the unity of the human race. No matter what our station or abilities in life, we are all mortal creatures who enter and exit this world with no choice in the matter. Life can be as painful as it is ephemeral, but it can also be joyous and wondrous. It is the tragedy and majesty of life that Carnival tries to reconcile. 


\title{
Neurology
}

\author{
The Carnival \\ Anthony Adamo \\ Neurology 2008;71;299-300 \\ DOI 10.1212/01.wnl.0000318219.30367.fb
}

This information is current as of July 21, 2008

\section{Updated Information \& Services}

Subspecialty Collections

Permissions \& Licensing

Reprints including high resolution figures, can be found at: http://n.neurology.org/content/71/4/299.full

This article, along with others on similar topics, appears in the following collection(s):

\section{Clinical neurology history}

http://n.neurology.org/cgi/collection/clinical_neurology_history

Information about reproducing this article in parts (figures,tables) or in its entirety can be found online at:

http://www.neurology.org/about/about_the_journal\#permissions

Information about ordering reprints can be found online:

http://n.neurology.org/subscribers/advertise

Neurology ${ }^{\circledR}$ is the official journal of the American Academy of Neurology. Published continuously since 1951, it is now a weekly with 48 issues per year. Copyright. All rights reserved. Print ISSN: 0028-3878. Online ISSN: 1526-632X.

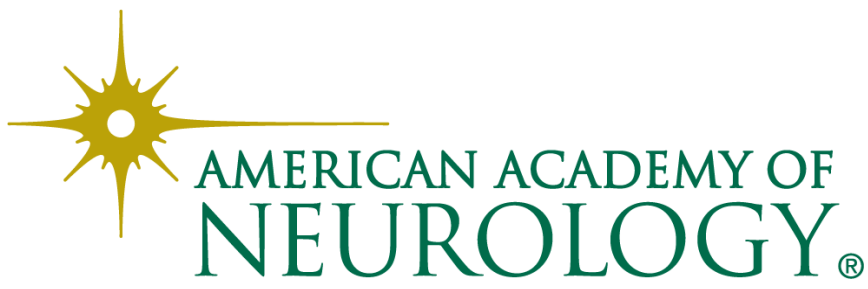

